\title{
2. STRUCTURAL FRAMEWORK OF THE CHILE MARGIN AT THE CHILE RIDGE COLLISION ZONE ${ }^{1}$
}

\author{
Nathan Bangs, ${ }^{2,3}$ Steven C. Cande, ${ }^{4}$ Stephen D. Lewis, ${ }^{5}$ and John Miller ${ }^{6}$
}

\begin{abstract}
Three multichannel seismic reflection lines collected as part of the site survey for drilling Leg 141 examine the structure of the active Chile margin in the vicinity of the Chile Triple Junction. These data are used to compare the margin structure along three cross sections that characterize the interaction of the Chile seafloor-spreading ridge as it collides with the Chile Trench and is subducted beneath the South American continent. Line 745 is located where the ridge is expected to collide with the lower trench slope in approximately 100 k.y. At Line 751 the ridge was subducted at approximately 50 ka. Line 762 examines the Taitao Ridge, which is thought to be an ophiolite that has been obducted onto the margin at the Taitao Fracture Zone.

The margin prior to ridge collision is characterized by a small accretionary complex and forearc basin that lie along the lower trench slope and abut attenuated continental crust underlying the middle and upper slopes. The tectonic interaction of the ridge with the margin appears minimal at this stage, with effects limited to those incurred by subducting a few large basement features that are not completely buried by the $100-400 \mathrm{~m}$ of trench-fill sediments. Where the ridge has recently been subducted, the tectonic interaction of the ridge is more pronounced. The toe of the small accretionary complex appears to have collapsed as the ridge passed beneath the lower trench slope and filled part of the large bathymetric depressions of the ridge axis that have not been filled by trench sediments. Comparison of the middle and upper slopes along the margin implies a large control by the continental crust on the morphology of the middle and upper slopes. Examination of the Taitao Ridge section shows considerable contrast in structure with the northern line. Here, much of the consinental slope is composed of a large igneous body thought to be ophiolite, and the thick trench-fill sequence shows no compressional deformation or active accretion.
\end{abstract}

\section{INTRODUCTION}

Between $45^{\circ} 40^{\prime} \mathrm{S}$ and $47^{\circ} \mathrm{S}$ the active Chile Ridge seafloorspreading center is colliding with the Chile Trench as it is subducted beneath the South American continent (Herron et al., 1977; Cande et al., 1987). In 1988, a 35-day multichannel seismic reflection and SeaBeam bathymetric survey was conducted on board the Conrad during cruise RC2901 to examine the structure of the margin where the ridge and trench collide. The purpose of acquiring these data was to examine the structural and stratigraphic fabric of the collision zone to investigate the interaction of the spreading center with the Chile margin, and to survey the region to locate sites for ODP drilling that would further elucidate processes of ridge/trench collision that have punctuated subduction history around the Pacific (Uyeda and Miyashiro, 1974; Grow and Atwater, 1970; Atwater, 1970).

The impact of the spreading ridge with the forearc can produce a distinctive structural and stratigraphic impression on the forearc as the young, buoyant, hot oceanic crust is subducted beneath the continental margin (DeLong and Fox, 1977; DeLong et al., 1978, 1979; Marshak and Karig, 1977; Herron, 1981; Barker, 1982; Thorkelson and Taylor, 1989). Investigations have shown that the principal geologic imprints left on the leading edge of an overriding plate from ridge/trench collisions are those produced by rapid uplift and subsidence of the margin, regional metamorphism from high thermal gradients, a cessation of arc magmatism and anoma-

${ }^{1}$ Behrmann, J.H., Lewis, S.D., Musgrave, R.J., et al., 1992. Proc. ODP, Init. Repts., 141: College Station, TX (Ocean Drilling Program).

${ }_{2}^{2}$ Lamont-Doherty Geological Observatory, Palisades, NY 10964, U.S.A.

${ }^{3}$ Present address: Institute for Geophysics, University of Texas at Austin, Austin, TX 78759, U.S.A.

${ }_{4}^{4}$ Scripps Institute of Oceanography, La Jolla, CA 92093, U.S.A.

${ }^{5}$ U.S. Geological Survey, Menlo Park, CA 94025, U.S.A.

${ }^{6}$ U.S. Geological Survey, Denver, CO 80225, U.S.A. lous near-trench magmatism, and extensional deformation and collapse of the margin with the passing of the spreading ridge. In southern Chile these effects may also be accompanied by tectonic removal of a large fraction of the forearc (Cande et al., 1987; Cande and Leslie, 1986) and the recent obduction of a piece of oceanic crust along the Taitao Fracture Zone (Leslie, 1986). The Taitao Ophiolite has been mapped where it is exposed on the Taitao Peninsula (Forsythe et al., 1986; Forsythe and Nelson, 1985). The offshore extension of the Taitao Peninsula, the Taitao Ridge, was also examined as part of this survey.

This chapter presents three seismic sections that intersect the Leg 141 drill sites. We investigate the tectonic and structural framework of the margin where it was drilled. These lines examine the final phases of spreading-ridge collision with the lower trench slope. A line just south of the Darwin Fracture Zone examines the initial collision phase, where the flanks of the ridge are beginning to enter the trench. Forty kilometers south, a transect examines the margin where the spreading ridge has been subducted $2 \mathrm{~km}$ beneath the lower trench slope. The third seismic section lies near the Taitao Fracture Zone where ridge collision has involved obduction of an ophiolite. The tectonic and structural settings of the ridge/trench collision are examined by presenting processed seismic reflection sections. Line 745 has benefited from sophisticated pre-stack depth migration.

\section{DATA ACQUISITION AND PROCESSING}

The seismic data were acquired with a Digicon 240-channel digital streamer on board the Conrad. The 3000-m streamer was divided into $12.5-\mathrm{m}$ groups to produce the 240 channels in the active array. Twelve-second records were digitally sampled at 4-ms intervals and recorded in demultiplexed form on 9-track tape using a Digicon DSS-240 recording system. Shots were located using ship's navigation, which was based on transit satellite positioning and dead reckoning for about $18 \mathrm{hr}$ of each day, and on more accurate GPS positioning when it was available. 
The seismic source consisted of a 10-gun array with a total volume of 3743 in. $^{3}$ The source was tuned to suppress reverberation from the bubble by the use of selected chamber sizes in the construction of the array. The array was fired at 20 -s intervals, equivalent to approximately every $50 \mathrm{~m}$ along the line, yielding 30 -fold common midpoint (CMP) coverage within the smallest possible bin size $(6.25 \mathrm{~m})$, and approximately 120 -fold within a $25-\mathrm{m}$ bin. The $25-\mathrm{m}$ bin size was used in all processing but the prestack depth migration, which used the $6.25-\mathrm{m}$ bins. The source signature remained reasonably consistent throughout the survey, as few mechanical difficulties were encountered with the air guns.

The processing was primarily conducted with facilities at Lamont-Doherty Geological Observatory. The initial processing consisted of making navigation corrections to produce a smooth, consistent ship's track for calculating CMP bins along the line, and editing noisy traces and bad shots. Most of the processing effort was spent in determining moveout velocities for stacking. Interpolation between broadly spaced velocity analyses on these data is subject to large errors due to uncertainties in the location of low-velocity slope cover and high-velocity continental basement. Stacking is especially sensitive where moveout for many of the reflectors is large due to the shallow water and slow sediment velocities. Velocity analyses were conducted at close spacing across the profiles to avoid interpolation across large distances. Semblance was calculated on every full-fold CMP (every $50 \mathrm{~m}$ ) on about half of each section, covering the areas that are particularly difficult to image. These were interpreted using a color graphics system on a workstation, and software to interactively examine the velocity analyses. A range of stacking velocities that bracketed those from the analysis was used to test if the amplitude and coherence of reflectors could be improved. Velocities were corrected to provide optimum stacks.

These data were post-stack migrated using DISCO software at the USGS facility in Palo Alto, CA. A finite-difference algorithm was used that could handle dipping events of up to $45^{\circ}$ dip. The data were migrated using stacking velocities, and velocities equal to $110 \%, 105 \%, 95 \%$, and $90 \%$ of stacking velocities, to determine best migration velocities.

In places, results from the collision zone are disappointing in terms of structural and stratigraphic information. Difficulties are partially the result of the inadequacy of the post-stack processing, partially from the rough, steep-surface topography of the slope (as seen in the SeaBeam bathymetry), and from the discontinuous, chaotic nature of the seismic horizons within this setting. Further sophisticated processing was conducted to eliminate some of the inadequacies of post-stack processing, and to provide an indication of how chaotic reflectors are along these lines, and how detrimental the effects of topography are.

Line 745 was also processed using a pre-stack depth-migration algorithm, MIGPACK, at Geomar in Kiel, Germany. MIGPACK downward-continues the wavefield alternately in common-shot and common-receiver gathers to migrate the energy, focusing it onto the zero-offset trace. Downward continuation is based on an input-velocity model that can be interactively evaluated on a workstation by maximizing the energy focused onto the zero-offset section. The migration process included an analysis of velocities to revise and improve velocities with each successive iteration. Pre-stack depth migration was advantageous in handling the problem of raypath distortion due to lateral velocity variations presented by the dipping structure of the continental slope. This method is far more sensitive to the velocity model than post-stack migration, and some differences in the images can be attributed to this sensitivity. Multiples in the CMP gathers were suppressed by $f-k$ filtering on the MIGPACK-processed section.

\section{THE RIDGE/TRENCH COLLISION}

The segment of the Chile seafloor-spreading ridge that is currently subducting beneath the lower trench slope lies between the Darwin and Taitao fracture zones, from $45^{\circ} 45^{\prime}$ to $46^{\circ} 18 \mathrm{~S}$ (Fig. 1). The spreading ridge is oriented slightly west of north and slightly oblique to the Chile margin, causing progressive subduction of the ridge segment from south to north. Segments of the ridge north of the collision zone have yet to be subducted, as they are offset to the west by a series of fracture zones oriented nearly perpendicular to the margin. To the south, segments of the spreading ridge have been subducted since the time the Chile Ridge initially collided with Tierra del Fuego at $14 \mathrm{Ma}$ (Cande et al., 1987). The segment currently being subducted initially entered the trench at the Taitao Fracture Zone at approximately $0.1 \mathrm{Ma}$. The Chile Triple Junction is currently located nearly midway between the Darwin and Taitao fracture zones, and is migrating north with ridge subduction. The ridge segment south of the triple junction has been buried by recent subduction and rapid trench sedimentation. The segment north of the Chile Triple Junction will be subducted within the next $0.15 \mathrm{~m} . \mathrm{y}$. if plate motions continue at current rates (Cande et al., 1987).

\section{LINE 745: 100 K.Y. PRIOR TO RIDGE COLLISION}

Line 745 (located in Figs. 1 and 2, shown in Fig. 3) lies at $45^{\circ} 55 \mathrm{~S}$ along the northern end of the subducting ridge segment, approximately $10 \mathrm{~km}$ south of the Darwin Fracture Zone and 18 $\mathrm{km}$ north of the present-day Chile Triple Junction. The axis of the spreading ridge lies approximately $5 \mathrm{~km}$ seaward of the toe of the slope on this line. This section provides a characterization of the margin at a stage just prior to ridge collision, as the ridge is expected to collide with the toe of the slope in approximately 100 k.y. Sites 859,860 , and 861 were drilled along this transect.

The axis of the spreading ridge on Line 745 lies just seaward of the trench between CMPs 600 and 800 (Fig. 3). There is considerable relief on the subducting crust, as a series of ridgeparallel normal faults offset the ridge flanks. The rift-valley wall is $400 \mathrm{~m}$ high on the seaward flank immediately adjacent to the ridge axis at CMP 600, with additional displacement on more seaward faults. Those faults become buried by a slope cover several tens of meters thick that infills the half-graben of the rift valley. The ridge is clearly asymmetric. The rift-valley wall on the landward side lies approximately $100 \mathrm{~m}$ deeper than its conjugate flank, probably reflecting the accumulated overburden of the lower slope and downward flexure of the oceanic crust as this flank enters the trench. The relief of the subducting crust is not buried by the trench fill, which is no more than $100 \mathrm{~m}$ thick immediately seaward of the lower trench slope. These sediments are presumed to be turbiditic sands, silts, and clays that are similar to the recent submarine fan deposits in the trench farther north (Scholl et al., 1970; Thornburg et al., 1990). These sediments are carried down the numerous canyons intersecting the slope (Fig. 2) and deposited in the trench. The basement ridge on the flank of the spreading center probably diverts turbidites northward parallel to the margin and traps them on the landward side of the trench that flow down the slope and migrate northward parallel to the margin. Profiles farther south show a thicker trench fill in the proximity of a large canyon just north of the Taitao Peninsula (Fig. 4).

The reflection from the top of the descending Nazca Plate can be traced approximately $15 \mathrm{~km}$ beneath the accretionary complex to where it is lost in the interference from the seafloor multiple. At the toe of the slope the plate dips about $7^{\circ}$. The plate dip increases locally to more than $15^{\circ}$ at about $10 \mathrm{~km}$ landward of the 


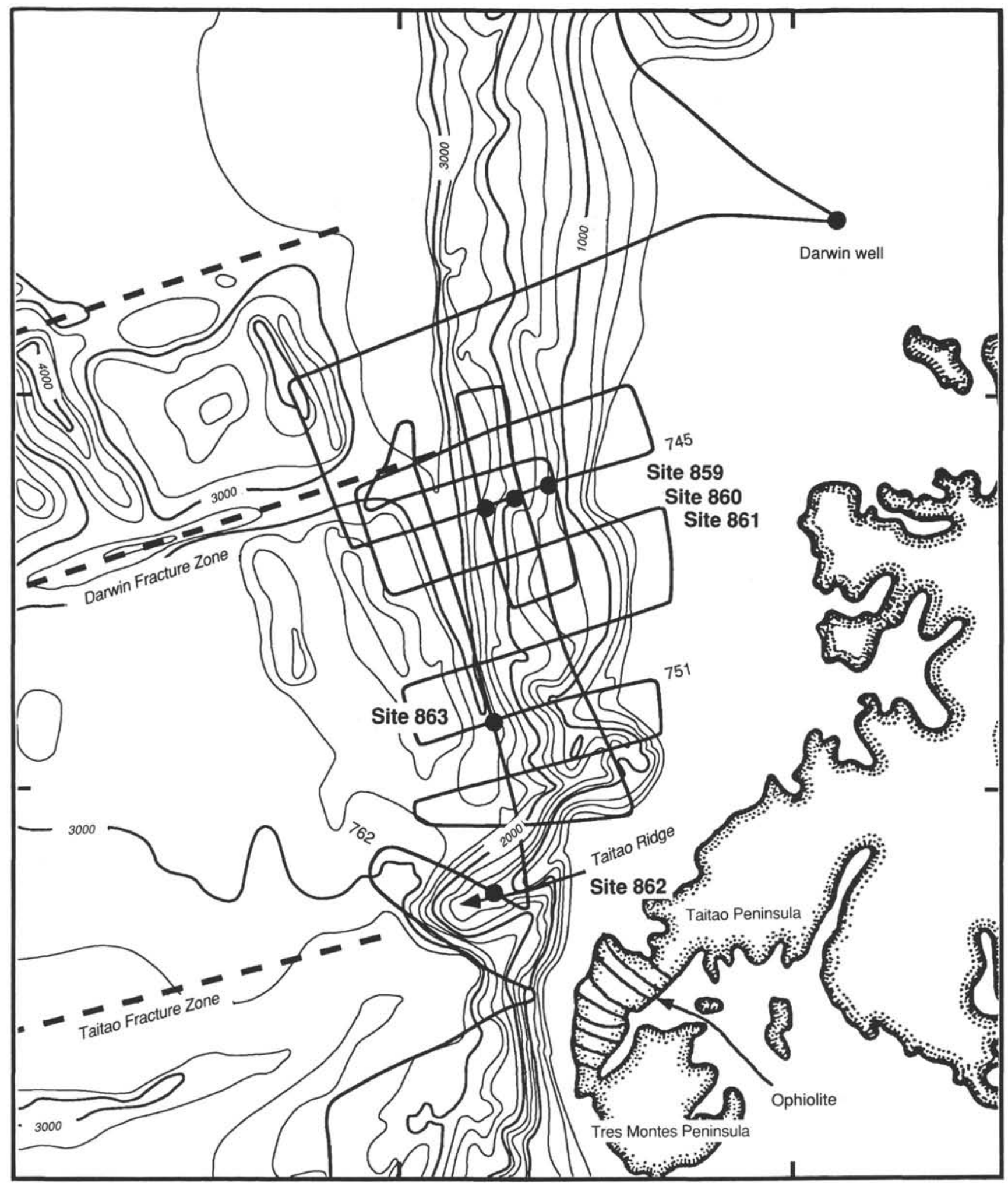

Figure 1. Bathymetric map of the Chile margin in the vicinity of the Chile Triple Junction. The Chile Ridge seafloor-spreading center between the Darwin and Taitao fracture zones is currently subducting beneath the South American continent. Shown are the locations of the seismic lines collected on board the Conrad as part of the site survey for Leg 141 drilling. Labeled Lines 745,751 , and 762 are presented in Figures $2-6$. The solid circles show the locations of the five sites drilled on Leg 141. 


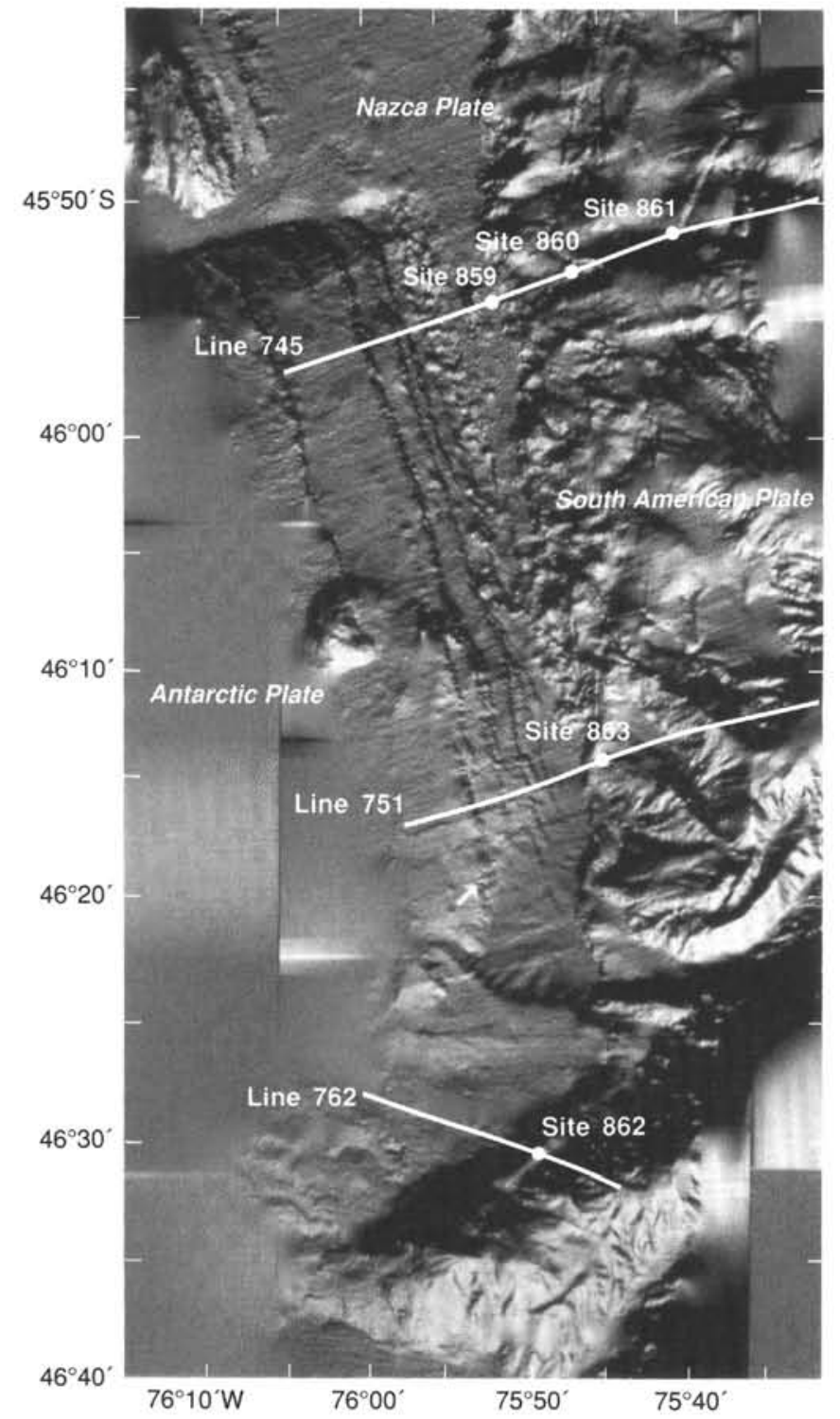

Figure 2. A processed image of the SeaBeam bathymetry showing the positions of the seismic lines presented here. North is to the top of the image. Line 745 is located where the seafloor-spreading center lies $5 \mathrm{~km}$ from the lower trench slope. At Line 751, the spreading ridge has been subducted and lies beneath the steep slope at the leading edge of the South American Plate. Note the large canyon in the east just south of Line 751 that feeds directly into the rift valley lying in the trench.

toe where a local basement high is currently passing beneath the mid-slope section of the margin. The velocities are not well constrained in this section, but both the analyses of the CMP gathers and the MIGPACK focusing analyses indicate a landward increase in the velocity of the sediments overlying the crust. Hence, this local basement depression is not an artifact of the time display.

A thin layer of trench-fill sediments on the oceanic crust is currently being accreted at the toe of the trench slope. A small wedge of chaotic reflectors marks the accreted trench sediments along the lowermost slope from CMP 950 to the break in seafloor bathymetry at CMP 1300 . The break in slope closely corresponds to the transition from rigid continental crust to less competent accreted sediments, as interpreted by von Huene et al. (1985) in the Chile Triple Junction region by analogy to profiles along the
Peru Trench. At the toe of the wedge, a series of parallel landward-dipping reflections are probably trench sediment sequences that have been accreted at the deformation front (Fig. 5). The trench fill is sufficiently thin that fault-bound thrust packets that comprise larger accretionary complexes (e.g., Karig, 1985) are not resolved on these profiles. Out-of-sequence faults are probably forming close to the deformation front to maintain critical wedge taper as they do offshore from Costa Rica (Shipley et al., 1992). These faults focus extensive deformation within the narrow accretionary complex and disrupt the coherent thrust packets to produce a wedge of discontinuous chaotic reflectors in the seismic section. Farther landward, the few coherent sequences become so intensely deformed that clear stratigraphic horizons are not recognizable in the seismic section. Discrete faults are also not recognized in the seismic section, and shearing may be pervasive throughout the accretionary complex rather than focused along distinct, well-developed shear zones. A bottom-simulating reflector (BSR) appears as a bright phase-reversed reflection on the post-stack migration that lies at about $250 \mathrm{~m}$ below seafloor at CMP 1650 and shallows to $100 \mathrm{~m}$ at CMP 1000 . The shallowing of the BSR reflects the shallowing of the gas hydrate stability field due to increased heat flow with proximity to the spreading ridge, as measured by Cande et al. (1987).

The décollement thrust between the descending plate and the overlying accretionary complex is not clearly imaged on Line 745 (Figs. 3 and 4). The décollement does not produce a prominent reflection and it is inferred to lie at the top of the undeformed reflectors overlying the oceanic crust. It lies about $100 \mathrm{~m}$ above the top of the subducting plate at the toe of the wedge. Continuous reflectors approximately 100 to $200 \mathrm{~m}$ thick lie parallel to the oceanic crust between 3.5 and $8 \mathrm{~km}$ from the toe and then appear to thicken landward.

A $750-m$ section of discontinuous reflections above the décollement that are nearly parallel to the descending crust below the décollement, was observed landward of $10 \mathrm{~km}$ from the wedge toe. These sequences may either be trench sediments thrust beneath the complex and underplated beneath the forearc basin, or structures that are part of the continental crust that is believed to extend seaward to this region. These reflectors do not dip as steeply as the overlying tilted sequences. A shift downward of the décollement into a basement low, such as that observed at CMP 1350 (Fig. 3), could provide a mechanism to underplate sections of the underthrust sediments. There is little evidence for well-developed ramp-flat-ramp structures commonly associated with underplating of thick sequences (Westbrook and Smith, 1983), or long relict décollement thrusts as observed offshore from Costa Rica (Shipley et al., 1992), so any underplating that is present has occurred in small, thin sections. Good velocity control to distinguish this sequence as underplated sediments rather than continental crust is not available from the CMP gathers; however, sediment velocities of $2.8 \mathrm{~km} / \mathrm{s}$, rather than high metamorphic crustal velocities, were derived from MIGPACK focusing analyses for pre-stack migration in the section 4 to $5 \mathrm{~km}$ beneath the forearc basin.

The underthrust layer is interpreted to thicken landward. The underthrust layer thickens because the trench-fill sequence fills this original seafloor depression. Reflectors lying parallel to the crust comprise this sequence. The trench fill is expected to have been thicker where less buoyant crust formed a deeper trench basin. Older crust would also have had more time to accumulate pelagic and hemipelagic layers such as those observed on older crust farther north (Thornburg et al., 1990).

The transition zone between the seaward margin of the continental crust and the accretionary complex is composed of a small ( $5 \mathrm{~km}$ wide) forearc basin from CMPs 1250 to 1550 (Fig. 3). An accumulation of approximately $1 \mathrm{~km}$ of sediments forms nearly 

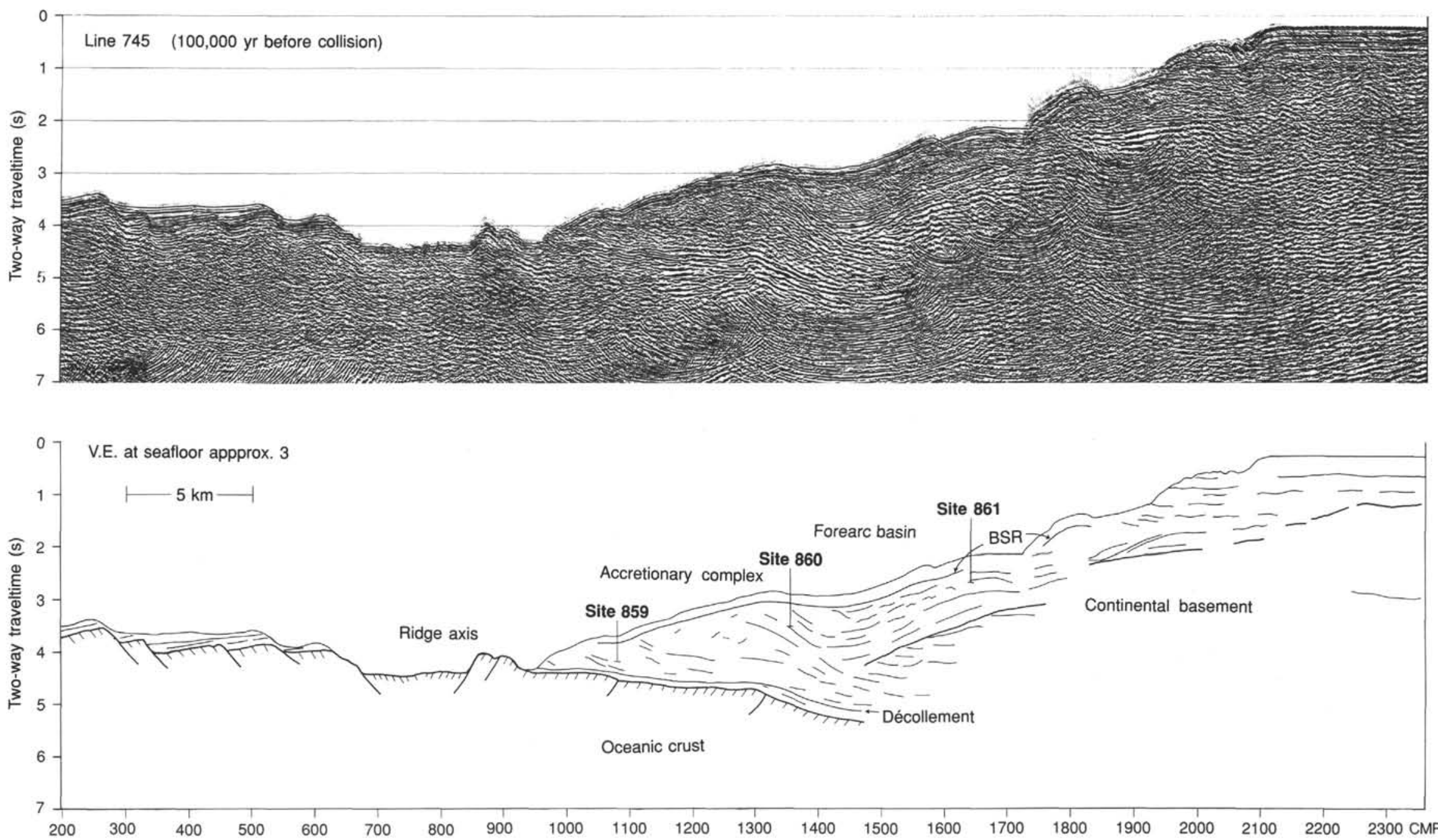

Figure 3. Seismic Line 745, located in Figure 1, is shown with a line-drawing interpretation. The seafloor-spreading ridge lies $5 \mathrm{~km}$ from the toe of the lower trench slope, and will be subducted in approximately 100 k.y. 

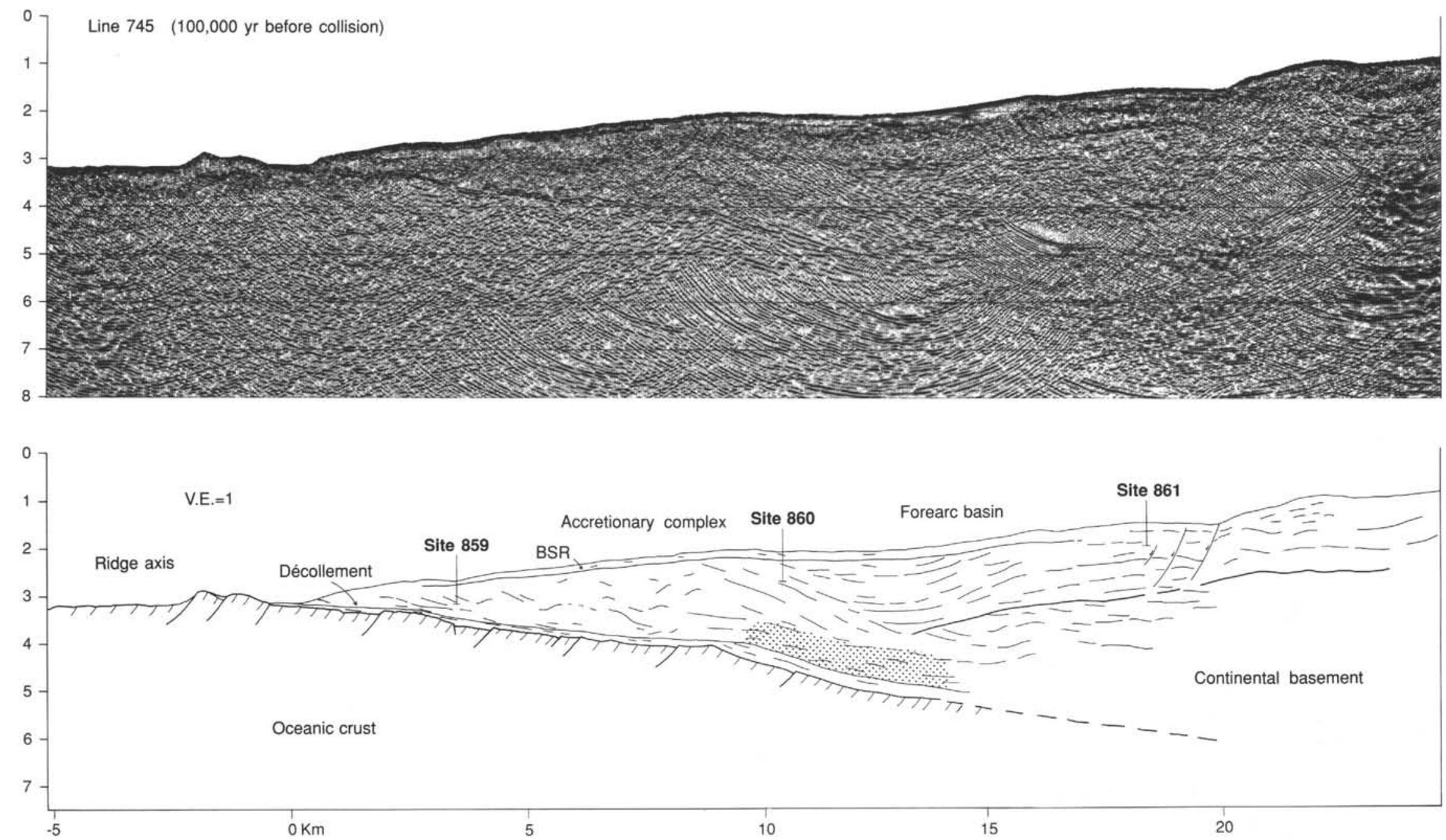

Figure 4. A true-scale pre-stack depth-migrated version of the midsection of Line 745 produced using MIGPACK. The stippled region possibly represents sediments that were subducted at the toe and underplated to the base of the wedge and forearc basin. 

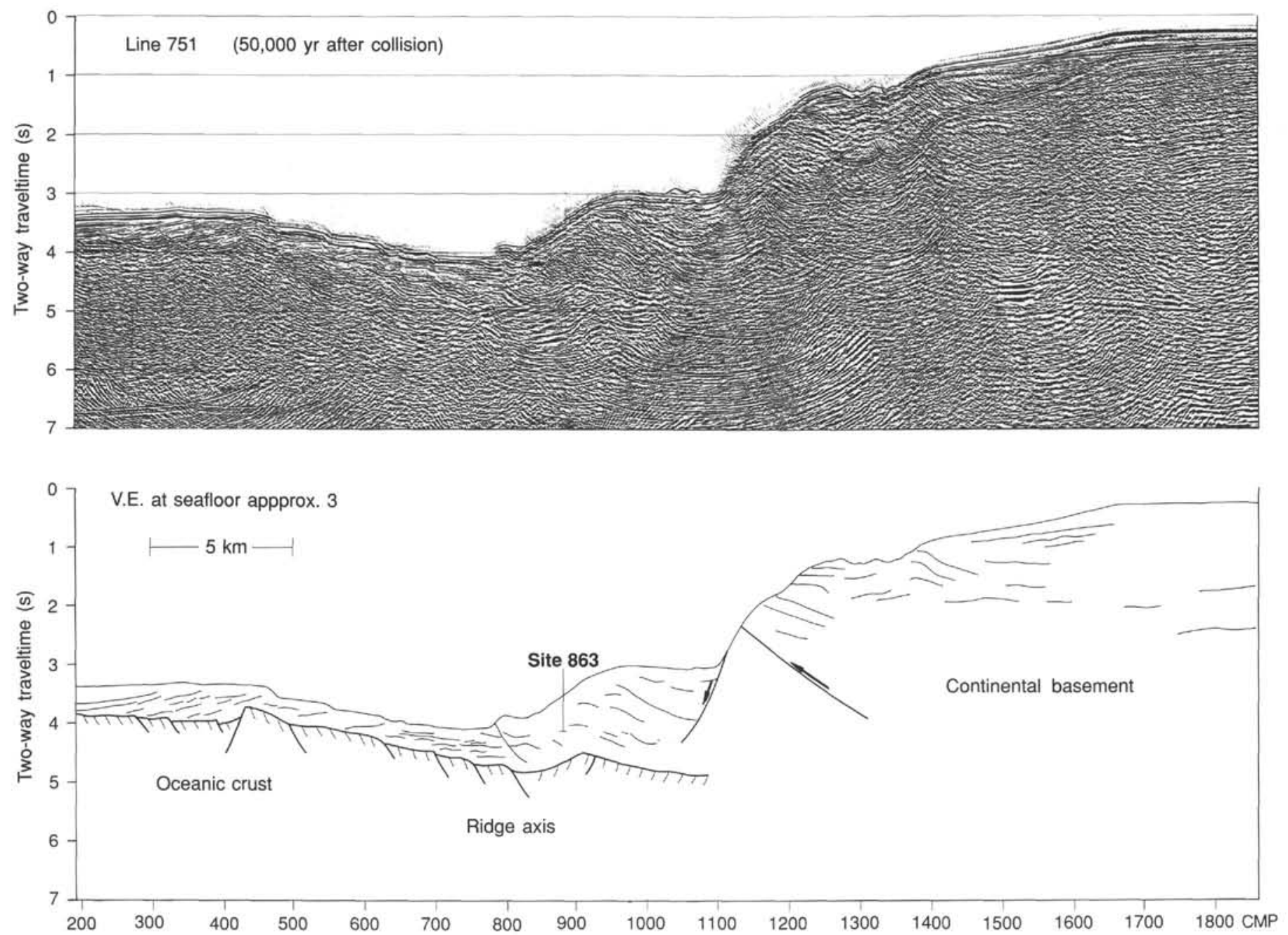

Figure 5. A post-stack migrated version of Line 751. On Line 751 the Chile Ridge has been subducted beneath the toe of the slope and was subducted within the last $50 \mathrm{k.y}$. The line drawing interpretation depicts two scenarios for the formation of the steep scarp in the midslope.

continuous reflectors across the basin that extend landward up onto the slope. The seawardmost basin sediments are uplifted into a broad syncline with the seawardmost horizons dipping east. The forearc basin is underlain on the eastern side by the seaward extent of the continental crust. A series of horizontal reflectors at 1.5-2 $\mathrm{km}$ below seafloor lies within the continental crust. These reflectors truncate against forearc basin sequences and lie unconformably beneath them (Fig. 4). These intrabasement reflectors lie subparallel to a prominent reflector $1.0 \mathrm{~s}$ sub-bottom (Fig. 3 ). The 1.0 -s sub-bottom reflector can be traced discontinuously to well beneath the shelf and into the continental fabric. The overlying slope cover sediments dip seaward a few degrees and imply subsidence of the center of the basin, or uplift of the landward side of the basin. Normal faults can be seen in the overlying slope cover in Figure 4. Offsets are a couple of tens of meters on these faults. Faulting is not as extensive as the midslope section offshore from Peru (von Huene et al., 1985), where the margin has undergone extensive collapse following subcrustal erosion.

The horizontal reflectors beneath the shelf and upper-slope sediment basins are presumed to be part of the metamorphosed Paleozoic accretionary terrain that is exposed on land (Mpodozis and Forsythe, 1983). This terrain is thought to comprise continental basement that extends across the shelf to the midslope. These reflectors extend from the right side of the section to a break in continuity at CMP 1800 and may connect to reflectors at the same depth below seafloor farther seaward. The overlying shelf and slope cover is presumed to be similar to that found where it was drilled $50 \mathrm{~km}$ north in the Darwin well (Fig. 1). At the Darwin well, $450 \mathrm{~m}$ of Pleistocene and upper Pliocene claystone and siltstone overlie $700 \mathrm{~m}$ of Pliocene and Miocene claystone and siltstone and a 100-m unit of Oligocene and Miocene conglomerate (Cande et al., 1987). The conglomerate ties with a bright seismic reflection that is interpreted to be acoustic basement. However, metamorphic basement was not reached at the bottom of the Darwin well at 1950 mbsf. A strong basement reflector can be seen just below $2.0 \mathrm{~s}$ in the vicinity of CMP 1900 . Along the upper slope, shelf sediments are truncated at the seafloor and are eroded between CMPs 1900 and 2100. A scarp on the seafloor at CMP 1700 implies a possible normal fault that may have as much as $500 \mathrm{~m}$ displacement; however, offsets in the slope cover appear to be less than a couple of tens of meters (Fig. 5), and some of the faulting may predate the overlying sedimentation.

\section{LINE 751: 50 K.Y. POST-COLLISION}

Line 751 (located in Figs. 1 and 2, shown in Fig. 5) lies at $46^{\circ} 15 \mathrm{~S}$ along the southern end of the subducting ridge segment, approximately $25 \mathrm{~km}$ north of the Taitao Fracture Zone and just a few kilometers south of the present-day Chile Triple Junction 
(Site 863). On this line, the axis of the spreading ridge was subducted beneath the toe of the slope at approximately $50 \mathrm{ka}$.

The top of the oceanic crust on Line 751 (Fig. 5) produces a strong reflection that can be traced from the left margin of the profile into the trench axis and $7 \mathrm{~km}$ beneath the toe of the lower trench slope. The thickness of the trench fill ( $400 \mathrm{~m}$ thick) is considerably greater than that seen on Line 745 because of its proximity to the large canyon just south that appears from the SeaBeam bathymetry to have filled in much of the trench at the mouth of the canyon (Fig. 2). Beneath the lower slope, the basement geometry is difficult to determine because of the large velocity pull-up from material overlying the crust between CMPs 800 and 950 . On the time section the top of oceanic crust appears to shallow between CMPs 800 and 900 , when it actually deepens by at least $600 \mathrm{~m}$. Despite the distortions on the time section, lateral trends in velocity of the overlying section confirm that a deepening of the crust at CMP 900 is not an artifact of the time display and probably represents a subducted ridge flank on the Nazca Plate. Assuming the width of the ridge axis is similar to that at Line 745, this places the rift valley between CMPs 750 and 900.

Despite the greater thickness of the trench fill on Line 751, the accretionary complex is narrower and smaller than on Line 745 . By analogy to Line 745 , the accretionary wedge is interpreted as the chaotic wedge of material that comprises the leading 5-7 km of the overriding plate. Except for a frontal ridge that appears to be pushed up at the base of the trench slope, thrust sequences of the accretionary complex cannot be identified, presumably due to the intense deformation of the wedge and partially due to the steepness of the surface slope, which dips here at about $12^{\circ}$. The slope here is nearly twice the $6.5^{\circ}$ slope on Line 745 due to oversteepening as subduction of the ridge axis depression causes collapse of the lower trench slope. Farther up the slope, landwarddipping reflectors appear continuous. The continuity may be better here because less subsidence and collapse has occurred than farther seaward. LGandward-dipping events between CMPs 950 and 1100 are probably a series of stratigraphic horizons within accreted thrust packets that have been rotated following subsequent accretion, or possibly deformed slope cover. An accumulation of slope cover several hundred meters thick lies on top of the wedge in the narrow zone between the wedge and the steep seafloor scarp to the east.

The continental shelf extends considerably farther seaward along Line 751 than Line 745 . The SeaBeam bathymetry map (Figs. 1 and 2) shows that Line 751 lies in a location where a large promontory protrudes from the shelf. Structures within the ridge are not clearly imaged due to seafloor multiples. The horizontal low-frequency reflector at CMP 1500 may extend laterally across a break between CMPs 1400 and 1300 to connect with the reflectors that appear to be truncated at the seafloor at CMP 1200. The few structures seen here show that the continental crust forms a shallow shelf until it terminates along a steep scarp. It is unclear if the scarp is produced by a large normal fault that may have left some of the hanging-wall block at the foot of the slope, or if thrust faulting has thickened the midslope section and steepened the surface slope. Both scenarios are depicted in Figure 5.

\section{LINE 762: THE TAITAO RIDGE TRANSECT}

Line 762 (location in Fig. 1, shown in Fig. 6) lies along the southernmost boundary of the currently subducting ridge segment just north of the Taitao Fracture Zone (Site 862). The line crosses the margin where a large promontory, the Taitao Ridge, extends seaward from the Taitao Peninsula. The Taitao Ridge is believed to be a fragment of oceanic crust in the process of emplacement during a late phase of ridge subduction (Leslie, 1986). An unmi- grated version of Line 762 is presented here, as it provides the best image of the section.

The major structures imaged on Line 762 consist of the oceanic crust covered by at least $700 \mathrm{~m}$ of sediments on the western side of the section, and to the east, a thick, acoustically structureless mound more than $10 \mathrm{~km}$ wide with virtually no sediment cover. The surface slope here is too steep for this ridge to be composed of weak accretionary complex material and is interpreted to be an igneous body that may be the seaward extension of the ophiolite that has been mapped on the Taitao Peninsula (Forsythe and Nelson, 1985). Large free-air gravity and magnetic anomalies also indicate that the Taitao Ridge is composed of high-density, magnetic material.

The top of the oceanic crust can be seen to dip toward the ridge and, presumably, the crust extends beneath it. It is difficult to trace the top of the crust landward beneath the base of the slope, probably due to the steep overlying slope and poor seismic penetration into the thick igneous material. It is uncertain what becomes of the oceanic crust beneath the ophiolite and whether subduction is active beneath the Taitao Ridge. The sediments overlying the oceanic crust are presumed to be detritus slumped off the massive igneous body into the trench, and turbiditic sequences from the major canyon to the north of the Taitao Ridge. One of the enigmas of this transect is that these trench-fill sediments show little tectonic disturbance or deformation that would indicate that any active thrusting has occurred in the trench since their time of deposition. It remains unclear how plate motions are accommodated along this segment of the margin.

\section{STRUCTURE OF THE CHILE COLLISION ZONE AND RIDGE INTERACTION}

The main structural components of the margin along the collision zone are characterized in their extremes by the two northern lines presented here, Lines 745 and 751 . The margin along Line 751 is composed mainly of the continental basement exposed on land that is buried by slope and shelf basin sediments. Basement extends seaward to where it is truncated along a sharp discontinuity marked by a steep slope. Abutting the continental basement is a small wedge of accreted material that has accumulated at the base of the slope with overlying slope cover between the wedge and its "backstop," the continental crust.

Along Line 745 , the characteristics of the continental framework and accretionary wedge contrast markedly with those along Line 751. Along Line 745, the continental basement thins more gradually across the shelf and has a less-abrupt truncation along the seaward margin. The surface of the continental crust probably plays a large role in the unevenness of the mid and upper slope seen in the SeaBeam bathymetry (Fig. 2). A larger accretionary complex has accumulated on Line 745 , and accreted sediments and forearc basin sediments form a wider, more gradual transition zone between the rigid continental basement framework and the deforming accretionary body. Older accreted sediments and possibly underplated material overlain by forearc basin sediments comprise some of this transition zone. Comparison with other seismic lines and SeaBeam bathymetry indicates that Line 745 is probably more representative of the margin in the collision zone than Line 751 is. The interpretation of the margin here is consistent with the general model of the Peru-Chile trench developed from seismic reflection data (von Huene et al., 1985), seismic refraction (Fisher and Raitt, 1962), and gravity models (Couch et al., 1981), that have shown that truncated, attenuated continental basement forms a buttress against which trench sediments are actively accreting to the lower trench slope.

Comparison of the margin just prior to and just after ridge collision suggests that the most apparent interaction of the ridge with the trench is due to basement topography associated with the 

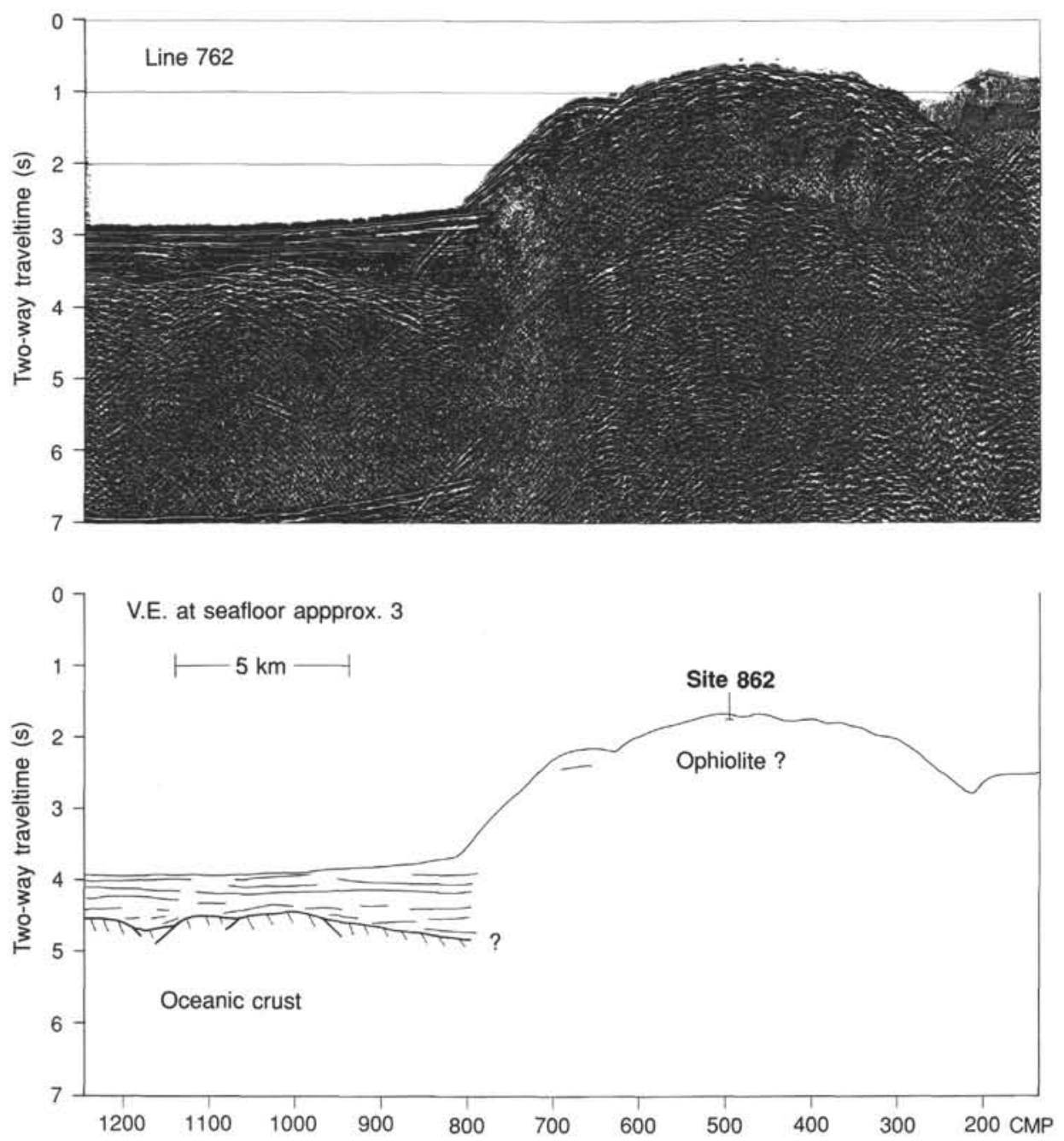

Figure 6. Seismic Line 762, located in Figure 1, crosses the Taitao Ridge. Shown here is an unmigrated version. The Taitao Ridge was the drilling target at Site 862 .

spreading ridge. Basement topography of the subducting crust is expected to play a significant role in the modification of the margin with subduction of the ridge because of (1) the increase in the basement relief and the inferred decrease in the trench-fill accumulation with decreasing age and increasing proximity to the spreading center and (2) the large influence of subducting basement structure on the stratigraphic position of the décollement thrust as documented by other studies (von Huene and Lallemand, 1990; Hilde, 1983). Influence from the oceanic crust topography can range from triggering underplating by a downward step in the décollement (Shipley et al., 1992) to forcing the décollement to rise to a shallower level above the basement relief and subcrustally erode the lower slope by entraining previously accreted material down the subduction zone with the crust (Hilde, 1983).

The small grabens observed beneath the seaward $7 \mathrm{~km}$ of the wedge on Line 745 are sufficiently small to be filled in with trench sediments and have little interaction with the overlying accretionary complex. However, the larger basement structures, such as that landward of $7 \mathrm{~km}$, probably have sufficient relief to interact by causing the wedge to be uplifted over the basement topography. They may also be forcing the stratigraphic position of the décollement to move up within the wedge to remove pieces of the forearc subcrustally. Horizontal reflectors on top of the subducting crust indicate the thickness of the trench fill is considerably greater than it is currently at the toe of the wedge, and the effect of the topography is subdued by sediment infilling. The greatest basement relief is associated with the ridge axis itself. Line $\mathbf{7 4 5}$ shows a $1.5-\mathrm{km}$-wide valley that is between 300 and $400 \mathrm{~m}$ high just seaward of the deformation front. The rift valley is now beneath the landward trench slope on Line 751. The volume of this valley is sufficiently large to cause considerable collapse of the landward trench slope, especially at Line 751 where the accretionary complex is small. Excessive oversteepening of the accretionary wedge appears to be the result of the initial underthrusting of the ridge axis. Further subduction implies that this material is in the initial stage of tectonic erosion and will be carried with the crust well into the subduction zone.

A fundamental question about this segment of the margin is whether the forearc is aggressively undergoing tectonic erosion, and if erosion is a product of ridge collision. A long history of erosion of the Chile coast has been proposed by Scholl et al. (1970) and Kulm et al. (1977), and erosion is believed to have shifted the coastline of South America as much as $200 \mathrm{~km}$ eastward since the Jurassic (Rutland, 1971). The small volume of material that has accumulated against the Peru-Chile margin (Kulm et al., 1982; Bangs et al., 1989) is taken as evidence that the subduction history along the Peru-Chile Trench may have been dominated by episodes of erosion. Erosion is believed to 
occur both frontally to produce the small accretionary complex observed here, and subcrustally to thin the continental crust and cause collapse of the forearc (von Huene and Lallemand, 1990; Cande and Leslie, 1986). The narrowing of the margin in the vicinity of the collision zone has been used as circumstantial evidence for extensive erosion triggered by ridge collision (Cande et al., 1987). The size of the accretionary complex along Line 745 is small. The complex could represent all that is left following extensive erosion of a larger accretionary complex. Although the trench fill is probably the thinnest it has been in recent subduction history, $100 \mathrm{~m}$, if all of it were accreted there is a sufficient supply of material to accrete the small accretionary complex in as little as $2-3 \mathrm{~m} . \mathrm{y}$. This is a small fraction of subduction history along this margin. Line 751 is even more extreme, as the trench fill is thicker and the accretionary wedge smaller. Therefore, we must also consider that the small wedge is not a product of extensive erosion of an older accretionary complex, but has instead accumulated recently and rapidly.

The structures observed in these data do not clearly distinguish between two distinct possibilities for the development of the margin. On Line 751, the prominent fault scarp may indicate that active tectonic erosion has subcrustally undermined and collapsed an older, larger accretionary complex; however, it is difficult to tie the existing hanging wall structures across the fault to conclude that they were once attached to the structures on the footwall of the scarp. This leaves open the possibility that faulting and truncation of the continental crust occurred prior to accretion of a young wedge and that much of the hanging-wall block has since been removed. A recent or current episode of tectonic erosion such as is documented offshore from Peru (von Huene and Lallemand, 1990) could also explain the apparent lack of material accumulated against the margin; however, there is little conclusive evidence in the slope cover for the tectonic subsidence following erosion and collapse that is clearly apparent offshore from Peru. The shallow surface slope of the wedge on Line $\mathbf{7 4 5}$ and the velocities determined for stacking and migration of the data imply that the wedge is not the core of an older, rigid, well-consolidated accretionary complex. This margin could be the product of erosion that has exposed an older wedge, but it is more likely that recent accretion has built up a wedge against an older, eroded, truncated margin.

There is also little evidence that ridge interaction has so far caused significant removal of the forearc. Contributions to erosion of the forearc from previously subducted ridge flanks are possible, but those observed here are sufficiently infilled with sediments that their effect is likely to be less than that of the ridge itself. While the ridge axis is of sufficient volume to cause collapse and some erosion of the forearc, it has not yet advanced far enough to account for a loss of significant portions of the forearc here. It is also unclear how the ridge could remove a large fraction of the forearc, as its size is small in proportion to the accretionary complex, and as seen on Line 751 , it is rapidly filled by trench sedimentation.

The structure exhibited on Line 762 contrasts considerably with the other two lines presented here, emphasizing the unusual character and collision history of the Taitao Ridge. The ophiolite discovered on the Taitao Peninsula is dated as roughly Pliocene (Forsythe and Nelson, 1985) making it roughly consistent in its timing with the arrival of the Chile Ridge in the segment south of the Taitao Fracture Zone. This timing provides good circumstantial evidence that ridge collision may trigger ophiolite obduction, a process that may also be an ongoing part of the current collision (Cande et al., 1987). The igneous body adjacent to the continental shelf that is seen on Line 762 is interpreted as a recently emplaced ophiolite (Leslie 1986; Cande et al., 1987). A young age is consistent with the observation of a lack of slope cover. While
Line 762 is believed to cross the active trench, the position of the décollement cannot be identified. Rapid trench deposition at the mouth of the large submarine canyon south of the Taitao Ridge makes it likely that this section records a short period of depositional history; however, the approximately $700 \mathrm{~m}$ of sediments on the oceanic crust at the base of the slope show no evidence of deformation since deposition. The décollement is inferred to lie within the ophiolite, rather than extending beneath it into the sediment section at the base of the slope. If so, then at least part of the ophiolite is attached to the Antarctic Plate and is continuing to be thrust beneath the forearc.

\section{CONCLUSIONS}

From examination of the margin at three locations that represent three phases of ridge collision we conclude the following:

1. The erosional effect of the ridge prior to collision of the rift axis appears to be limited to the small amount of erosion that is possible from the largest of the subducting bathymetric features. Only crustal relief greater than the sediment cover of 100-200 m is capable of forcing the décollement to step up into the preexisting accretionary complex to cause erosion. The volume of material observed to be lost in this fashion is small due to insufficient basement relief on the Nazca Plate and the large amount of sediment infilling of basement topography on the young crust.

2. Most of the impact of the ridge collision occurs as the ridge subducts beneath the toe of the lower slope. Collapse of the lower slope into the ridge axis occurs as the ridge is thrust beneath the lower slope. This material will probably eventually be removed with subduction of the rift axis.

3 . The large variation in margin structure is largely a product of earlier truncation of the continental crust against which recent sediment accretion has accumulated a small accretionary complex. The majority of the tectonic modification of the margin by ridge collision will occur in the remaining phases of ridge subduction.

\section{ACKNOWLEDGMENTS}

We thank R. von Huene for the use of facilities at GEOMAR to process Line 745 and for helpful discussions about these data. D. Klaesen provided extensive assistance in processing at GEOMAR, as well as J. Childs and E. Geist at the USGS. Discussions with G. Westbrook about these data and review by T. Shipley are greatly appreciated. This work was supported by NSF Grant No. OCE 85-11388 and JOI Grant No. 9-91.

\section{REFERENCES}

Atwater, T., 1970. Implications of plate tectonics for the Cenozoic tectonic evolution of western North America. Geol. Soc. Am. Bull., 81:3513-3536

Bangs, N., Cande, S.C., Lewis, S.D., and Tebbens, S., 1989. Seismic evidence for tectonic erosion at the Chile Margin-Chile Ridge collision zone. Eos, 70:1314.

Barker, P.F., 1982. The Cenozoic subduction history of the Pacific margin of the Antarctic Peninsula: ridge crest-trench interactions. J. Geol. Soc. London, 139:787-802.

Cande, S.C., and Leslie, R.B., 1986. Late Cenozoic tectonics of the southern Chile Trench. J. Geophys. Res., 91:471-496.

Cande, S.C., Leslie, R.B., Parra, J.C., and Hobart, M., 1987. Interaction between the Chile Ridge and Chile Trench: geophysical and geothermal evidence. J. Geophys. Res., 92:495-520.

Couch, R., Whitsett, R., Hehn, B., and Briceno-Guarupe, L., 1981. Structures of the continental margin of Peru and Chile. Mem. Geol. Soc. Am., 154:703-726.

DeLong, S.E., and Fox, P.J., 1977. Geological consequences of ridge subduction. In Talwani M., and Pitman, W.C., III (Eds)., Island Arcs, Deep Sea Trenches, and Back-arc Basins. Am. Geophys. Union, Maurice Ewing Ser., 1:221-228. 
DeLong, S.E., Fox, P.J., and McDowell, F.W., 1978. Subduction of the Kula Ridge at the Aleutian Trench. Geol. Soc. Am. Bull., 89:83-95.

DeLong, S.E., Schwartz, W.M., and Anderson, R.N., 1979. Thermal effects of ridge subduction. Earth Planet Sci. Lett., 44:239-246.

Fisher, R.L., and Raitt, R.W., 1962. Topography and structure of the Peru-Chile trench. Deep Sea Res. Part A, 9:423-443.

Forsythe, R.D., and Nelson, E., 1985. Geological manifestation of ridge collision: evidence from the Golfo de Penas-Taitao Basin, Southern Chile. Tectonics, 4:477-495.

Forsythe, R.D., Nelson, E., Carr, M.J., Kaeding, M.E., Herve, M., Mpodozis, C., Soffia, J.M., and Harambour, S., 1986. Pliocene near-trench magmatism in southern Chile: a possible manifestation of ridge collision. Geology, 14:23-27.

Grow, J.A., and Atwater, T., 1970. Mid-Tertiary transition in the Aleutian arc. Geol. Soc. Am. Bull., 81:3715-3722.

Herron, E.M., 1981. Chile margin near lat. 38 S: evidence for a genetic relationship between continental and marine geologic features or a case of curious coincidences? Mem.-Geol. Soc. Am., 154:755-760.

Herron, E.M., Bruhn, R., Winslow, M., and Chuaqui, L., 1977. Post-Miocene tectonics of the margin of southern Chile. In Talwani, M., and Pitman, W.C., III (Eds.), Island Arcs, Deep Sea Trenches and Backarc Basins. Am. Geophys. Union, Maurice Ewing Ser., 1:285-302.

Hilde, T.W.C., 1983. Sediment subduction vs. accretion around the $\mathrm{Pa}$ cific. Tectonophysics, 99:381-397.

Karig, D.E., 1985. The framework of deformation in the Nankai Trough. In Kamagi, H., Karig, D.E., Coulborn, W.T., et al., Init. Repts. DSDP, 87: Washington (U.S. Govt. Printing Office), 927-940.

Kulm, L.D., Resig, J.M., Thornburg, T., and Schrader, J.J., 1982. Cenozoic structure, stratigraphy, and tectonics of the central Peru forearc. In Leggett, J.K. (Ed.), Trench-Forearc Geology: Sedimentation and Tectonics on Modern and Ancient Active Plate Margins: Oxford (Blackwell), 151-170.

Kulm, L.D., Schweller, W.J., and Masias, A., 1977. A preliminary analysis of the subduction processes along the Andean continental margin, $6^{\circ}$ to $45^{\circ} \mathrm{S}$. In Talwani M., and Pitman, W.C., III, Island Arcs, Deep Sea Trenches, and Back-Arc Basins, Am. Geophys. Union, Maurice Ewing Ser., 1:285-302.
Leslie, R.B., 1986. Cenozoic tectonics of southern Chile: triple junction migration, ridge subduction, and forearc evolution [Ph.D. thesis]. Columbia Univ., New York, NY.

Marshak, R.S., and Karig, D.E., 1977. Triple junctions as a cause for anomalous near-trench igneous activity between the trench and volcanic arc. Geology, 5:233-236.

Mpodozis, C., and Forsythe, R., 1983. Stratigraphy and geochemistry of accreted fragments of the ancestral Pacific floor in southern South America. Palaeogeogr., Palaeoclimatol., Palaeoecol., 41:103-124.

Rutland, R.W.R., 1971. Andean orogeny and ocean floor spreading. Nature, 233:252-255.

Scholl, D.W., Christensen, M.N., von Huene, R., and Marlow, M.S., 1970. Peru-Chile Trench sediments and sea-floor spreading. Geol. Soc. Am. Bull., 81:564-568.

Shipley, T.H., McIntosh, K.D., Silver, E.A., Stoffa, P.L., 1992. Three-dimensional seismic imaging of the Costa Rica accretionary prism: structural diversity in a small volume of the lower slope. J. Geophys. Res., 97:4439-4459.

Thorkelson, D.J., and Taylor, R.P., 1989. Corilleran slab windows. Geology, 17:833-836.

Thornburg, T.M., Kulm, L.D., and Hussong, D.M., 1990. Submarine-fan development in the southern Chile Trench: a dynamic interplay of tectonics and sedimentation. Geol. Soc. Am. Bull., 102:1658-1680.

Uyeda, S., and Miyashiro, A., 1974. Plate tectonics in the Japanese islands: a synthesis. Geol. Soc. Am. Bull., 85:1159-1170.

von Huene, R., Kulm, L.D., and Miller, J., 1985. Structure of the frontal part of the Andean convergent margin. J. Geophys. Res., 90:5429 5442.

von Huene, R., Lallemand, S., 1990. Tectonic erosion along the Japan and Peru convergent margins. Geol. Soc. Am. Bull., 102:704-720.

Westbrook, G.K., and Smith, M.J., 1983. Long décollements and mud volcanoes: evidence from the Barbados Ridge Complex for the role of high pore-fluid pressure in the development of an accretionary complex. Geology, 11:279-283.

\section{Ms 141IR-102}

